\author{
Len Smith, Janet McCalman, Ian Anderson, Sandra Smith, \\ Joanne Evans, Gavan McCarthy, and Jane Beer
}

\title{
Fractional Identities: The Political Arithmetic of
} Aboriginal Victorians The debate over the size of the Aboriginal population of Australia on the eve of the European invasion has been complicated by the nation's unsavory "history wars." The smaller the number of original inhabitants, the lower is the implied number of colonial casualties and the more defensible appears the claim that a people of the plough had a right to convert a seemingly empty land into a food basket for the empire. However, as scholars have come to understand the complexity of Aboriginal society and its management of plant and animal food resources, they have also gained a new appreciation of the land's carrying capacity. Indeed, the belated discovery of women's significance as food gatherers has revealed the extent to which Aboriginal people were reliant on the gathering of the vegetable and invertebrate food resources to be found in previously unappreciated abundance throughout the continent, as well as the extent to which they systematically managed those resources by fire, aquaculture, and proto-agriculture. Len Smith has estimated that this

Len Smith is a Visiting Fellow at the Australian Demographic and Social Research Institute, Australian National University. He is the author of The Aboriginal Population of Australia (Canberra, 1980); co-editor, with Gordon Briscoe, of The Aboriginal Population Revisited: 70000 Years to the Present (Canberra, 2002).

Janet McCalman has a personal chair in the School of Population Health, University of Melbourne. She is the author of Sex and Suffering (Baltimore 1999); co-author, with Ruth Morley and John Carlin, of "Birth Weight and Coronary Heart Disease in a Cohort Born I 857-I900 in Melbourne, Australia," International Journal of Epidemiology, XXXV (2006), 880885 .

Ian Anderson is Professor of Indigenous Health, and Director of the Centre for Health \& Society, University of Melbourne. He is the author of "Aboriginal Society and Health: Critical Issues Demand What from Sociologists?" Annual Review of Health Sociology, X (2002), 5-20; co-author, with B. L. Loff, of "Voices Lost: Indigenous Health and Human Rights in Australia," Lancet, CCCLXIV (2004), I28I-I282.

Sandra Smith is a research officer in Indigenous Cultures, Museum Victoria. Joanne Evans is Deputy Director of the eScholarship Research Centre, University of Melbourne. Gavan McCarthy is Director of the eScholarship Research Centre, University of Melbourne. Jane Beer is a research assistant, School of Population Health, University of Melbourne.

This research in this article was funded by the Australian Research Council and supported by Museum Victoria. The authors thank Nicholas Knight and Kate Naughton for data entry.

(C) 2008 by the Massachusetts Institute of Technology and The Journal of Interdisciplinary History, Inc. 
so-called "terra nullius" would have supported around I.6 billion human lives past infancy during an estimated 70,000 years of human occupation before British colonization-scarcely an empty land that belonged to no one. ${ }^{1}$

THE COLONIAL DECLINE OF THE ABORIGINAL POPULATION There has been considerable variation in the estimates of the original population of Australia before European colonization. It is said that Arthur Phillip, first British Governor, estimated the population of the whole continent when it was annexed in I788 to be around I million, although there is now a dispute over whether this estimate was ever made. Later estimates by explorers and government officials were based on observations of concentrations of people whose numbers may already have declined because of introduced diseases. In I930, A. R. Radcliffe-Brown, who reviewed the available literature on settler observations, frontier violence, and introduced disease, determined the original population to be at least 250,000 and possibly in excess of 300,000. Subsequent archaeological research that has rewritten modern understandings of Aboriginal society, ecological practice, and food gathering, now makes an estimate of I million in I 788 seem implausibly low for a land mass of such size and resources. ${ }^{2}$

I Stuart Macintyre and Anna Clark, The History Wars (Melbourne, 2003); Robert Manne (ed.), Whitewash: On Keith Windschuttle's Fabrication of Aboriginal History (Melbourne, 2003); Keith Windschuttle, The Fabrication of Aboriginal History. I. Van Diemen's Land 1803-1847 (Paddington, U.K., 2002).

John Howard, the current Australian Prime Minister, dismissed as "political correctness" the description of the European settlement of the Australian continent as an "invasion," but most Aboriginal people remember it as such. Similarly, the "history wars" have questioned the extent of frontier violence. The conservative historiography prefers to focus on the role of disease and Aboriginal "backwardness" as more significant than frontier violence; other historians would argue that the demographic impact of smallpox subdued indigenous resistance to invasion. The European settlers were sometimes welcomed as visitors, but never embraced as permanent co-habitants; their animals soon monopolized access to water and pasture. In Victoria, Aboriginal resistance grew after communities were able to regroup, and the local terrain provided cover for guerrilla-type operations. To argue that settlement was not an invasion is to deny that Aboriginal people had a deep historical claim to collective possession of the land. This dispute underlines the necessity for empirical research into the demographics of the transition from a precolonial to a colonized population. See Richard Broome, Aboriginal Victorians: A History since 1800 (Sydney, 2005).

John Mulvaney, “Difficult to Found and Opinion': I 788 Population Estimates,” in Gordon Briscoe and Len Smith (eds.), The Aboriginal Population Revisited: 70 ooo Years to the Present (Canberra, 2002) I-8; Smith, "How Many People Had Lived in Australia Before It Was Annexed by the English in I788?" ibid., 9-I 5 .

2 Broome, Aboriginal Victorians. 
A similar profusion of estimates about the size of the Victorian population emerged both in I 788 and in I 835 , when the first settlement was established at Port Phillip. Until recently, a consensus had developed, based on Radcliffe-Brown's work, that about I 5, ooo people occupied the area south of the Murray River before the British occupation. However, that figure must be considered an absolute minimum, given the evidence of decline until I850, summarized by Barwick and others.

Since then, the work of Butlin, Webb, and Campbell has resulted in a substantial increase in the supposed population. The southeast corner of the Australian continent was probably the most densely populated part of Aboriginal Australia, with sufficient food supplies to support a semi-sedentary society and economy along the Murray River and parts of the western basalt plain. This population was affected by two successive smallpox epidemics around I 788 and I 829 that swept across the southeast ahead of the colonial frontier: Curr (I883), Brough Smyth (I 876), and numerous others reported that the initial epidemic reduced the tribes as far away from Sydney as the Murray estuary by half. Broome argues that the figure of I 5,000 must refer to the population at the founding of the colony in I 835 , and that if each epidemic resulted in 50 percent mortality, the precolonial population must have been about 60,000 . Hence, by the time that the colonial capital of Melbourne was formally settled in I835, the Aboriginal population had already fallen by 75 percent. Figure I portrays our tentative reconstruction of the colonial population decline and its subsequent recovery. ${ }^{3}$

Just eighteen years later, in I 853, official counts placed I,907 Aborigines and 6.5 million sheep in Victoria, but the European invaders were quickly making up the human deficiency; half a million gold seekers surged into the colony in a decade. Because the entire colony was closely settled, from I835 onward, the

3 Diane E. Barwick, "Changes in the Aboriginal Population of Victoria, I863-I966," in Mulvaney and Jack Golson (eds.), Aboriginal Man and Environment in Australia (Canberra, I97I), 288-3 I5; Noel G. Butlin, Our Original Aggression (Sydney, I983); Judith Campbell, Invisible Invaders: Smallpox and Other Diseases in Aboriginal Australia, 1780-1880 (Melbourne, 2002); Stephen Webb, "Intensification, Population and Social Changes in South-eastern Victoria: The Skeletal Evidence," Aboriginal History, VIII (1984), I54-172; Harry Lourandos, Continent of Hunter-Gatherers: New Perspectives in Australian History (New York, I997); Edward M. Curr, Recollections of Squatting in Victoria, Then Called the Port Phillip District (from 1841-1851) (Melbourne, I965; orig. pub.I883); R. Brough Smyth, The Aborigines of Victoria: With Notes Relating to the Habits of the Natives of Other Parts of Australia and Tasmania (Melbourne, I 878); Broome, Aboriginal Victorians. 
Fig. 1 The Aboriginal Population of Victoria, I780-200 I

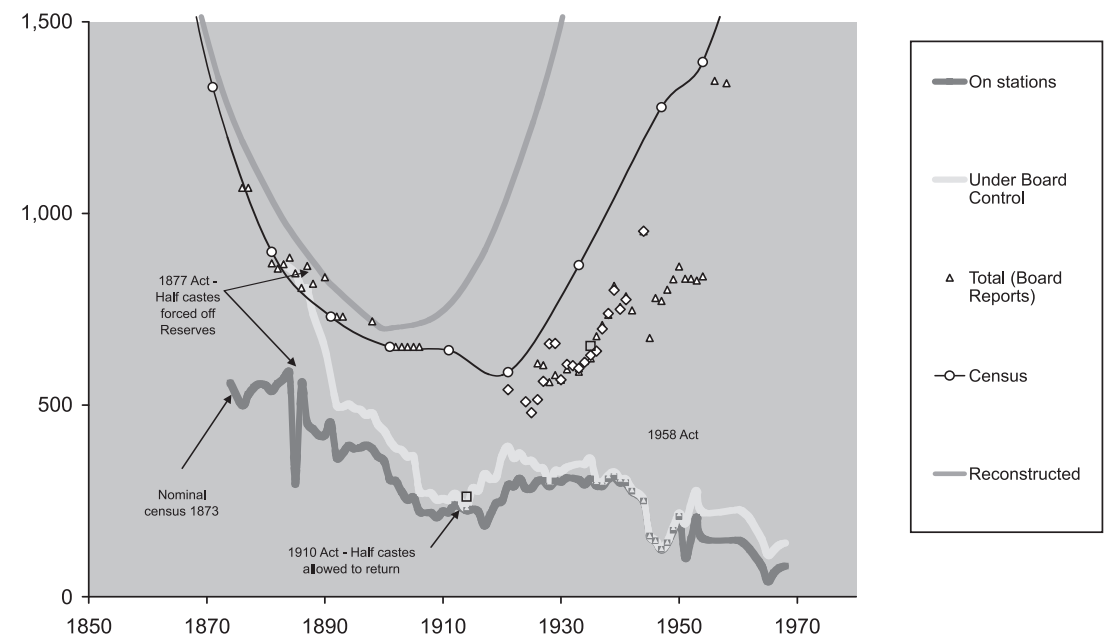

Aborigines were restricted in their movements, and alienated from their hunting and foraging lands. They were subject to high mortality, not only from tuberculosis, syphilis, and other diseases, but also from settler violence. Births were few, and the population went into a rapid decline. ${ }^{4}$

By the time of Australian Federation in I90I, I.2 million whites and 652 Aborigines, by official calculation, were in Victoria, plus I I million sheep and I.6 million cattle: The colonization of Victoria was arguably the most rapid and most catastrophic colonial dispossession of the nineteenth century. In the course of a single human lifespan, the authorities could be confident that the "native population" in Victoria was fading away. In I993, when the "last of the tribe," Mary Angeline Morgan, died, racial purists could claim that Aboriginal Victoria had evaporated into the mists of time. ${ }^{5}$

VICTORIAN DISTINCTIVENESS The immense wealth found in Victoria's goldmines lured more educated and capitalized immigrants during the I850s. Almost all of them paid their own way; for a

4 Smith, The Aboriginal Population of Australia (Canberra, I980).

5 Phillip Pepper and Tess De Araugo, The Kurnai of Gippsland (Melbourne I985), 262. 
time, the colony had the highest level of literacy in the British Empire. Of the half a million who came in the I 850 , half of them settled permanently - among them physicians, scientists, artists, and artisans with progressive views who were anxious to build a better society. Australasia's first medical society and professional medical journal were established in the I 850 s, as were a Royal Society for those with scientific interests; a new university; a public library; a public museum; and a host of voluntarist welfare, health, and educational institutions. Victorians prided themselves on building a democracy that realized many of the Chartists' principles - a protectionist political economy benefiting both manufacturers and workers, a strong civic and intellectual culture, and a progressive native administration. ${ }^{6}$

The colonial government had been quick to establish rationing stations, missions, and even schools. George Augustus Robinson was appointed Chief Protector of Aborigines in I839 in the hope of preventing the disastrous de-population that had occurred in Van Diemen's Land. A protectorate existed until I 849. A Select Committee in I859 led to the formation of a Central Board to Watch Over the Interests of Aborigines, which by I 862 superintended seven reserves and twenty-three small camping places. Victoria's I869 Act, which established safe havens to protect the remnants of the tribes from the excesses of the settlers, became the model for legislation in the rest of the country decades later. It also marked, however, the beginning of coercive native administration in Australia: From that point forward, Aboriginality - and by extension, a person's status under the Act-came under the jurisdiction of a magistrate. The act controlled Aborigines' place of residence, movement outside the reserves, work contracts, money, and children's welfare. ${ }^{7}$

NATIVE ADMinistration AND THE "HALF CASTE PROBLEM" When the Central Board for the Protection of Aborigines replaced the earlier Board for the Aborigines in I869, its objective was to protect the native people from the abuse of the settlers; about half of

6 Graeme Davison, "Gold-Rush Melbourne," in Iain McCalman (ed.), Gold: Forgotten Histories and Lost Objects of Australia (New York, 200I) 52-53; Geoffrey Serle, The Golden Age: A History of the Colony of Victoria 1851-1861 (Melbourne, 1977); Davison, The Rise and Fall of Marvellous Melbourne (Melbourne, I978).

7 Broome, Aboriginal Victorians, I20-I32, I46-I 52. 
the surviving Aborigines were collected together on its stations. Our research indicates that the protection that the Board afforded the station residents was certainly effective. The half of the population that did not live on the reserves seems to have left few identifiable descendants; only a handful of families is known to have survived outside the Board's protection. But even though many of their lives were saved, the station residents were clearly not protected from interactions with settlers. ${ }^{8}$

The circumstances and intimate details of the relations between white men and Aboriginal women in colonial Victoria will probably always remain largely hidden from historians. Existing accounts derive from censorious third parties, who saw the situation in terms of prostitution, exploitation, and depravity; they give little insight into the personal and social dynamics of the "union of the races," as the Select Committee had coyly termed it. What is known, however, is that more and more Aboriginal women living on the Board's stations began to bear children whose fathers were white. The "union of the races" proceeded so rapidly that on stations controlled by the Board, "half-castes" outnumbered "fullbloods" by the late I 88 os. The majority of mixed-race children, if they survived, became the responsibility of their mothers to be raised on the stations as Aborigines. ${ }^{9}$

These "part-Aboriginal" people living as Aborigines caused great concern to the colonial government and the emerging colonial society. They challenged both the policy and fiscal basis of native administration. The assumption was that the Aborigines would gradually disappear in the face of the superior British civilization and that the Board's budget, never adequate, would reduce in concert with the native population. To official and popular objections that people of mixed descent should not be receiving protection or relief were added calls for a reduction in the cost of maintaining the stations and complaints that the reserves were occupying land that could be made available to settlers. ${ }^{10}$

LEGISLATING ABORIGINALITY: FRACTIONAL IDENTITY AND FRACTIONAL CITIZENSHIP These concerns were addressed by the Vic-

$8 \quad$ Ibid., I46-I65.

9 Victoria Parliament, Legislative Council, Select Committee on the Aborigines: Report (Melbourne, I 859); Report of the Board for the Protection of Aborigines I889 (Melbourne, I889); Barwick, "Changes," 299.

IO Barwick, "Changes," 289-29I. 
torian Aborigines Protection Act of I886, known generally as the "half-caste Act," and described in the I 887 Protection Board Report as "a measure for merging the half-castes among the general population of the colony." The new Act sought to accelerate the "natural historical process" of assimilation, absorption, and therefore disappearance of Aboriginal Victoria from the human story, by simply declaring - in the name of economy and of the peoples' own best interest - that persons of mixed descent were not $\mathrm{Ab}-$ origines and were not entitled to live on stations nor to receive aid as a right. With certain provisos, upon reaching maturity these people were to leave the reserves and become members of the general community, to "make their own way, with occasional assistance from the Board." This policy set the pattern for the solution of the "half-caste problem" throughout Australia for the next eighty years. Aboriginal people were divided into "full-bloods," who remained entitled to full rationing on the Aboriginal reserves, and those of fractional Aboriginality, who were denied access to life and support on the reserves, no matter how close were their ties of kinship and association to those permitted to remain. ${ }^{11}$

This political arithmetic of race spawned elaborate charts of "blood predominance"; racial theorizing waxed and waned in response to international intellectual and political tides. As Broome outlined, the "fractions" varied from Act to Act in Victoria: In I 886, "half caste" meant any degree of mixed blood, but according to the I9I6 regulations, those with one-eighth or more of white blood had to leave the stations, implying that only those less than one-eighth white were Aboriginal and authorized to stay on reserves. The Aboriginal Act of I928 stated that the Board could not expend money on "octoroons" and "quadroons," meaning that only people less than one-quarter white were to be deemed Aboriginal. ${ }^{12}$

In I956, the State Government established an inquiry into the operation of the I928 Act, conducted by Charles McLean, a retired magistrate. Despite his instructions to investigate those of one-quarter descent or more, McLean in his report recognized that all Victorians of Aboriginal descent were suffering from deprivations and discrimination and urged the government to adopt a wider definition. Hence, the new I957 Act, which abolished the

I I Broome, Aboriginal Victorians.

I2 Warwick Anderson, The Cultivation of Whiteness: Science, Health and Racial Destiny in Australia (New York 2003; orig. pub. Melbourne, 2002). 
Board, reverted to the I 886 definition - that is, any admixture of Aboriginal blood. ${ }^{13}$

REGULATION OF THE FAMILY Australian native policy was unique in its "animal husbandry" approach to assimilation - in the Australian context, meaning the physical assimilation and disappearance of the Aboriginal people-which was based on a combination of the separation of caste groups, the regulation of marriage, and the removal of children. In theory, the "Victorian solution" since I 886 had sought the absorption and eventual disappearance of a "dying race" through the dilution of "blood" and the encouragement of miscegenation. Indeed, marriages that might "strengthen the blood" were to be discouraged and even prevented. In practice, doing so meant that a "fractional Aboriginal identity" was insufficient to justify support as an Aboriginal person, but sufficient to deny equality, both legal and cultural, with whites. Aboriginal veterans from both world wars, for instance, found that their equality on the battlefield evaporated once they returned to claim their veterans' entitlements. As Barwick recorded, people bitterly recalled, "We were too black to get work, or State Relief, and too white to get help from the Board."14

Despite the passage of the I 886 Act, the objective of making people of mixed descent disappear into the general population was never accepted either by Aborigines or by whites. Those "half castes" expelled from the reserves after the adoption of the Act and thereby thrust into the terrible economic conditions of the I $890 \mathrm{Os}$ depression had to compete for work and survival with thousands of unemployed urban and rural people. Far from "merging with the general population of the colony," they found that the "general population of the colony" was unwilling to accept them. Unable to find work or accommodation, most of them were relegated to shanty settlements on the margins of the reserves or nearby towns. As Broome pointed out, however, many of those entitled to receive support fled the reserves because of the oppressiveness of the regime. Even when the Board was enabled in I9Io to give assistance to people other than those of full descent, few

I 3 Broome, Aboriginal Victorians, I86, 203, 244, 3 I 4, 3 I6.

I 4 Katherine Ellinghaus, “Taking Assimilation to Heart: Marriages of White Women and Indigenous Men in Australia and North America, I870s-I930s," unpub. Ph.D. diss. (University of Melbourne, 2002); Barwick, "Changes," 29I. 
chose to return to the reserves, though most were living in poor conditions outside. ${ }^{15}$

THE “INVISIBLE' ABORIGINES" Despite being told by the Board and the law that they were not Aborigines, people not living on the reserves knew whether they were Aborigines or not, as did the local authorities and white people who in daily life discriminated against them as such. But, since they were progressively excluded from the Board's population statistics, they appear not to have recorded themselves as Aborigines in the censuses conducted by the colonial, state, and Australian statistical authorities. Instead, they joined a reservoir of statistically invisible Aborigines that developed for Ioo years as a direct product of Victorian native administration. ${ }^{16}$

In I92I, the Victorian census count of Aborigines reached its lowest point, just 586, and, as late as I96 I, it numbered fewer than 2,000. But in 200I, at the first Australian Census of the new millennium, almost 30,000 people in Victoria affirmed that they were of Aboriginal origin. Natural increase in a "closed" population without any source of external growth from immigration cannot explain this extraordinary recovery, and it would require a higher level of family formation than is indicated in any historical record. The inescapable inference is that the source of growth was a hidden population that was not officially Aboriginal in the eyes of the law or the authorities. Smith pointed to the re-emergence of these previously invisible people in the census counts since I966 when he reviewed the population history of the Victorian Aborigines in I980. ${ }^{17}$

The process accelerated in I97I when, for the first time, the Australian census invited people to identify themselves as Aboriginal rather than as some racial fraction. Not surprisingly, as indigenous identity became less stigmatized, the number of Aboriginal people nationwide grew rapidly with each subsequent censusnowhere more so than in Tasmania and Victoria, states where the Aboriginal population was officially "extinct." In Victoria, the

I5 Barwick, "A Little More Than Kin: Regional Affiliation and Group Identity among Aboriginal Migrants in Melbourne," unpub. Ph.D. diss. (Australian National University, I963); Broome Aboriginal Victorians.

I6 Smith, Aboriginal Population of Australia.

I7 Ibid. 
process produced amazing growth rates of almost 20 percent a year for several decades. In the I960s, an Aboriginal political movement emerged, increasingly framed around such values as autonomy, self-determination, and land rights. ${ }^{18}$

This political organization coincided with a resurgent interest among Aboriginal peoples in Aboriginal arts, culture, and heritage, especially in Victoria. Aboriginal people resisted the categorization of caste that the authorities had deployed in the interest of racist administrative policy, re-asserting clan and regional identities in its place. In this new social milieu, the statistical recognition of Aboriginal people in population counts was accompanied by an insistent politics that demanded the recognition of a continuous, albeit colonized, historical presence.

GENEALOGICAL IDENTITY Aboriginal Victorians, even those not officially counted as Aboriginal or situated on reserves, had retained their identity, their community, and their culture. They defined Aboriginality as they always had, as a matter of cultural identification and community recognition. The glue that bonded them was genealogy and "country." Barwick found in the I96os that most of the older adults had a genealogical knowledge that was "extraordinarily vast"; they could "reconstruct the complete history of their own families and, indeed, most of the cognate stocks of the same home region, dating back to the founding couples born in the I850s or earlier." By the I960s, the descendant population had entered its seventh generation. Researchers turned to these genealogies and memories when they began to explore Victorian Aboriginal family and population history in the I930s as well as in the I960s. Genealogy offered a key to finding a people who were supposed to have disappeared and whose defining characteristic - their race- had been removed from the contemporary record. ${ }^{19}$

This article determines how Aboriginal Victorians both survived and regrouped. It sheds light on the disappearance and subsequent re-emergence of the invisible Aborigines by studying the genealogies of today's Aboriginal Victorians-reconstituting the Aboriginal population backward and combining family histo-

I 8 Verity Burgmann, Power Profit and Protest: Australian Social Movements and Globalisation (Sydney, 2003).

I9 Barwick, "Changes," 296-297. 
ries with information contained in the colonial censuses and vital registrations, and in the Board's censuses. Out of respect for the privacy of Aboriginal people and their ancestors, it does not identify people by name but reconstructs their demographic history from sources in the public domain. This method is made possible by the remarkable historical record of colonization created by the government of the new colony and the statisticians who established what was arguably the most sophisticated system of vital registration in the nineteenth-century Anglophone world.

\section{SOURCES AND METHODS}

Vital Registrations and Colonial Censuses In I 853, the colony of Victoria appointed William Henry Archer acting RegistrarGeneral and Government Statist. He was a disciple of William Farr, the pioneering epidemiologist and statistician who led the General Register Office of England and Wales for four decades. Archer put Farr's principles into practice. Henceforth, the registration of births, deaths, and marriages mandated a full record of kinship, social position, and geographical identification. Moreover, a uniform nosology regulated the certifications of death, including as many as four contributing or allied morbidities with estimates of their duration.

The colony was divided into registration districts, each with its own trained deputy-registrar. Aboriginal births, deaths, and marriages were recorded along with those of whites. In many cases, the registrars took pains to record the white biological fathers on birth certificates as well as the social Aboriginal fathers, documenting for posterity the sexual exploitation of Aboriginal women by some of Victoria's most prominent early colonists and the apparent legitimacy accorded to it. The colonial censuses conducted under the direction of Archer, and later H. H. Hayter, are also unique in directly documenting the decline of the indigenous population as it was occurring. The statistical data on the Victorian Aboriginal population are, therefore, of extraordinary quality and quantity: Census estimates of the population are available from I 836 to I $84 \mathrm{I}$, and full counts thereafter. ${ }^{20}$ 
Protection Board Censuses While the Aborigines were being counted in the colonial censuses, the Aborigines' Protectorate and the Board for the Protection of Aborigines were conducting their own censuses. Robinson, the first Protector appointed in I838, was instructed to take a complete census of the Aboriginal population - the number in each family, and the age, name, sex, and tribe of each individual. The first attempt in I 839 was only partly successful, but subsequent years, particularly after I $85 \mathrm{I}$, saw numerous censuses undertaken and published in the Board's reports. In contrast to the colonial censuses, these censuses preserve many of the individual records, and this study has incorporated them into its database. ${ }^{21}$

As forced assimilation increasingly became the Board's policy, its statistics included more and more distinctions and fractional divisions within the population- "full bloods," "half castes," and "quarter castes" — and showed separate figures for those living "on stations," "under the control of the Board," and "in contact with the Board." Remarkably, the Board also provided an enumeration of those deemed not to be Aborigines at all. Figure 2 reveals the changes over time in these different populations. Because most of these totals derive from lists with the names of the individuals involved, they are reliable.

Reconstituted Identities: The Koori Health Research Database (KHRD) The foundation of this article's research-a population reconstituted from genealogical records of the current Victorian Aboriginal population - is informed by the work of many others over a long period. This research carefully traced the spouses and children of all identified individuals forward in time and their parents and siblings backward in time. In I938/39, Norman Tindale collected genealogies of people from the Cummeragunga and Lake Tyers mission stations, now held at the South Australian Museum. Hamilton Hendry recorded some families from Lake Tyers in the I950s, and Alan West and Aldo Massola, curators at the Museum of Victoria, collected oral histories and genealogies in the I960s. Archival sources include the papers of John Bulmer and A. W. Howitt, both held by Museum Victoria. ${ }^{22}$

Melbourne: Family Life in the Late Nineteenth Century (Canberra, I994); John M Eyler, Victorian Social Medicine: The Ideas and Methods of William Farr (Baltimore, I979).

2I Jan Critchett, A Distant Field of Murder (Melbourne, I990).

22 A. W. Howitt Papers, Museum Victoria and State Library of Victoria; J. M. Bulmer, Papers, Museum Victoria. 
Fig. 2 Subgroups of Victoria's Aboriginal Population

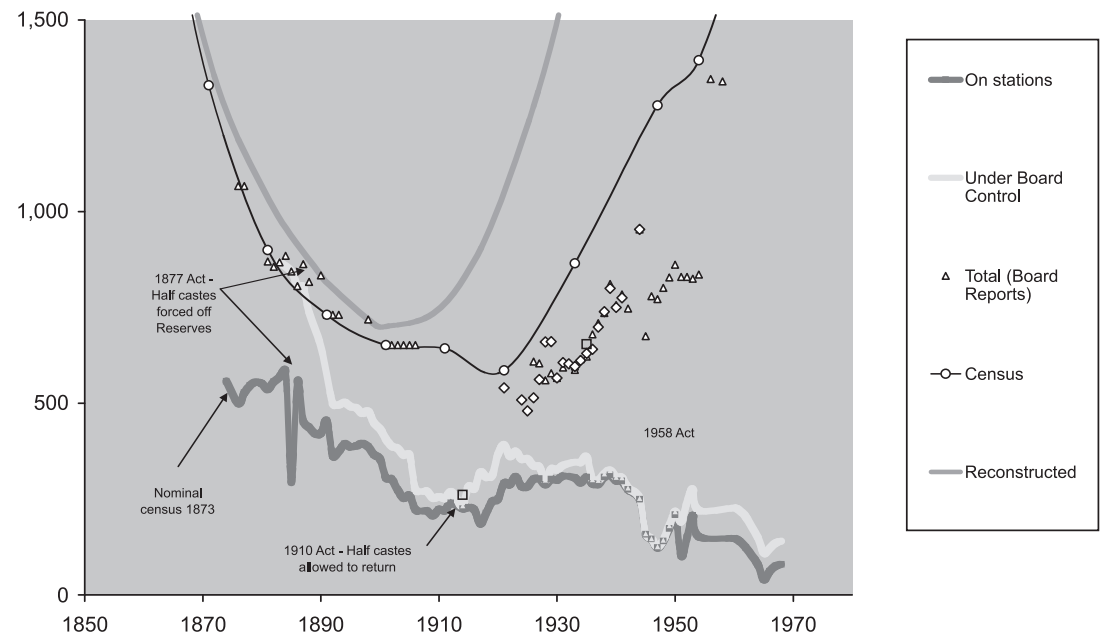

The major contributions after Tindale came from Barwick, who began work on Aboriginal Victorians in I960, and from Alick Jackomos at the Australian Institute of Aboriginal and Torres Strait Islander Studies (AIATSIS). Barwick collected extensive oral histories and combed the reports of the Protection Board and the mission stations to construct detailed genealogies. She had limited access to Victorian birth, death, and marriage certificates for the confirmation of identities and dates, but her genealogies were available, in part, to other researchers at Museum Victoria. Barwick died prematurely in I986. Until 2005, her full archive of drafts, research notes, and genealogies remained with her widower and daughter. In 2004, the Australian Research Council (ARC) provided funds that enabled the archive to be indexed online by Anne McCarthy of the University of Melbourne eScholarship Research Centre (eSRC) in preparation for the collection's donation to the State Library of Victoria and eventually to be opened for general scholarly and community use. ${ }^{23}$

Since 1987, Sandra Smith, an Aboriginal genealogist, has worked in the Aboriginal Heritage program at Museum Victoria, collating and checking all of these sources of family history and

23 http://www.esrc.unimelb.edu.au/; for access to the Guide to Records, http:// www.austehc.unimelb.edu.au/guides/barw/. 
entering them into a CGenerations genealogical database. The Museum uses this resource to provide a confidential family history service to members of the Victorian Aboriginal community attempting to re-establish family connections. In I999, an ARC grant enabled the employment of research assistants to collect information from the records of Victorian Aboriginal welfare administration in the Australian Archives, as well as other historical sources, and to incorporate them in the Museum's (CGenerations database. Funds from the ARC grant covered the cost of accessing the birth, death, and marriage certificates of individuals in the reconstituted genealogies, permitting the information in the genealogies to be checked. Other documentary sources - such as police, court and prison records - served to validate and enrich the genealogical data. $^{24}$

The grant also funded the creation of the KHRD by Evans and McCarthy of the eScholarship Research Centre at the University of Melbourne, who used their own Access-based software, the Online Heritage Resource Manager (OHRM). The KHRD takes family data from (CGenerations, disaggregates it into individual records, reconciles multiple references to individuals, and incorporates them in a normalized relational database. This database is flexible, fully searchable for both individuals and families, largely free of duplications, and exportable into statistical databases for epidemiological and demographic analysis. The material from the Barwick archive, particularly the genealogies and census lists of individuals, will be consulted in depth as a final source for the genealogical and historical data collated in the KHRD. When she died, Barwick was still reconstructing the ancestral Aboriginal population based on her genealogies. The availability of the KHRD database and the indexing of Barwick's archive allow us finally to finish her work. ${ }^{25}$

24 I999 ARC Large Grant: A/ Ian Anderson, Janet McCalman, and Ruth Morley: \$ I68,000 for "A Demographic and Socio-Medical History of the Aboriginal People of Victoria, I80o2000: Colonisation and Epidemiological Transitions."

25 This second stage, including the indexing of the Barwick Papers, was funded by 2004 ARC Discovery Grant: \$22I,ooo-McCalman, Anderson, McCarthy, Zhongwei Zhao, Barwick, "A Demographic and Socio-Medical History of the Aboriginal People of Victoria, I 800-2000: Reconstitutions and Epidemiological Analysis." Beer conducted archival research and undertook the birth, death, and marriage certificate searches. The results were analysed by Len Smith, an epidemiologist and demographer of Aboriginal Australia; he and McCalman wrote the historical text; Anderson provided sociomedical analysis. 
Fig. 3 Evidence from KHRD of the Movement of Victoria's Aborigines into and out of the Census and Protection Board Populations

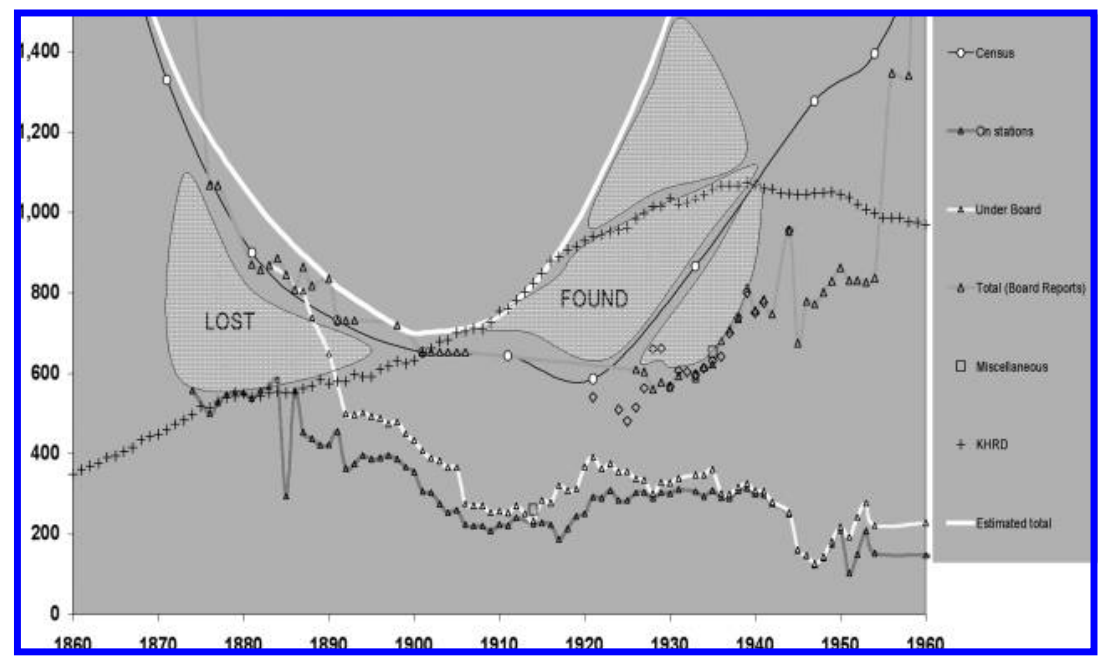

RECONSTITUTING VICTORIA In combination with the historical statistical sources, the quantitative evidence from this study's analysis of the population reconstituted from the genealogies brings clarity to two central aspects of Victorian Aboriginal population history-the colonial decline and the disappearance and reemergence of the invisible Aborigines. Figure 3, which compares the population reconstituted from the genealogies with the numbers derived from the colonial and Protection Board censuses, has two striking features, one of them expected and the other a complete surprise. The first is the direct, unprecedented documentation of the size and evolution of the invisible Aboriginal. The second is the fact that the current Victorian Aboriginal population seems to have descended from the approximately 500 individuals collected on the Board's reserves in the I870s. The other 500 to I, 000 people recorded by the Board and the colonial census as living outside the reserves appear to have left scarcely any descendants except a handful of families who, significantly, had some land of their own. Even they were in contact with the Board and in receipt of assistance from time to time. Eventually, some of 
these families married back into the Aboriginal community under the Board's control. ${ }^{26}$

The Emergence of the Invisible Aborigines from the Shadows In I980, Smith argued that only the existence of a substantial group of invisible Aborigines, excluded from the Aboriginal population until the abandonment of the assimilation policies, could explain the rapid growth in the census population since the I96os. He further argued, that the size of the gap between the population before and after the period in which the policy flourished-as revealed by past census and Board statistics and the hypothetical population ancestral to the current census Aboriginal population-implied that the invisible Aborigines must have diverged from the known Aborigines a long time ago. The KHRD data now provide the first explicit evidence that Smith was correct: In Victoria, the census population began to fall below the population ancestral to today's Aborigines in the I 890 s, during the era of forced assimilation, and the gap widened as more and more people of mixed descent joined the invisible group. The KHRD also reveals that the population reached its lowest level of about 900 in the 1890 , rather than the low point of under 600 in I92 I indicated by the census. Twice as many appear to have become statistically invisible by that time.

Smith's I980 analysis was based on the I97I census, which enumerated fewer than 6,000 Aborigines in Victoria. Given that the population in $200 \mathrm{I}$ stood at about 30,000 , the emergence of previously invisible people has clearly continued apace. Unfortunately, the KHRD becomes progressively less complete after I92I. Although it includes all known deaths, because it excludes births from I92 I (records of which are not available to the public), the process of rejoining the enumerated population cannot be documented in detail. That it occurred is certain, however, as witnessed by the explosive growth since i966.

From the I880s to the I950s, when the Victorian authorities continued to promote the policy and mythology of absorption,

26 Broome, Aboriginal Victorians, I56-I65. Indigenous genealogists believe that some individuals, children and young women, were rescued by settlers and absorbed into European families. Some may have preserved a memory of their origin that now enables them to reidentify with the Aboriginal community - particularly in Tasmania, where Aboriginal identity is strongly contested between those descended from the "official" Aborigines on the Bass Strait islands and those whose identity has been preserved only by family and community memory. 
striving to keep the recognized population to an absolute minimum, the reservoir of invisible Aborigines was swelling at the rate of about 3 percent a year. As Figure 3 shows, the agreement between the Board's figures and the censuses between I89I and I92 I indicates that the great number of "part-Aborigines" that the KHRD reveals to have been excluded from the Board's figures were also excluded from the census; they were either not enumerated or, more likely, they were not identified as Aborigines-by themselves or by the census enumerators. Since the Board's figures remain well below the census figures from I92 I to I954, clearly not all people of mixed descent accepted the Board's dictum that they were not Aborigines, at least on the census form. Even without the births, the KHRD population remains substantially higher than either the censuses or the Board's figures during this period. ${ }^{27}$

The effect of government race policy on the figures is particularly striking when the McLean Commission marked the end of the assimilation policy in I957. Once Victoria's substantial Aboriginal population gained official recognition, and the government came to accept responsibility for all persons of Aboriginal descent, both the census and Board figures showed an immediate, dramatic climb. Just as the Board's estimates led the way down, they also led the way up, and the census quickly followed. Between I954 and I97I, the census population and the Board's figures more than quadrupled; the number enumerated at the census continued to grow at almost 20 percent a year until I96I. The Board's estimates were based on complete records of all Aboriginal families. They represented nearly complete counts of the total number of persons who acknowledged Aboriginal descent. ${ }^{28}$

The Colonial Decline The population reconstructed from the genealogies also adds to information about the colonial decline. These painstaking forward- and backward-looking genealogies are

27 Another aspect of the resistance to the Board's policies involved people declining to categorize themselves as "half-castes." Between I954 and I966, many more people were identified as "full-bloods" in the census than were recognized as such by the State; fewer were prepared to call themselves "half-castes." Only a fraction of these people were identified as Aborigines, but even that small number was sufficient to bring the census "half-castes" above the State figures between I933 and I954.

28 Charles McLean, Report upon the Operation of the Aborigines Act 1928 and the Regulations and Orders Made Thereunder, Victorian Parliamentary Papers, 1956-57, No. I8; Phillip Felton, "No Reliable Records," unpub. M.A. thesis (University of Sydney, I98I). 
highly unlikely to have omitted substantial numbers of people. Yet, surprisingly, if the genealogies are correct, the entire current population of Aboriginal Victorians are descended from that half of the population that the Board collected at its stations in I 863 .

What happened to the other half of the population that appears to have left no descendants at all? Who were they? The obvious interpretation is that, not being under the Board's protection, they were killed by settlers, or they died because they lost access to their traditional economic resources. Elder, Clark, Critchett, and others have documented the extent to which these outcomes occurred in Gippsland and the Western District. But the people who left no descendants could also have been the parents or childless siblings of Aborigines under the Board's protection, or they might have been beyond the Board's reach precisely because they were unmarried, childless, or without living relatives. ${ }^{29}$

Partial answers to these questions appear in the rich colonial censuses, which from I 856 included counts of the Aboriginal population. Every census contained extremely detailed information on the geographical distribution of the population. Preliminary examination of the populations by land divisions in the censuses from I86I to I90 I-aggregating divisions as necessary to obtain a consistent time series-discovers that the people outside the Board's protection who left no descendants were not the scattered parents or childless relatives of those protected by the Board (see Figure 4). Rather, they were whole populations in the frontier regions-particularly in the Wimmera, the last-settled part of the colony. Within three decades, they had disappeared from the administrative record. Whether they died out entirely or were absorbed into other Aboriginal communities across colonial and state borders remains an open question.

This population reconstitution resolves long-standing uncertainties about the fate of Aboriginal people in Victoria in the colonial and postcolonial era. The findings would not have been possible without the integration of genealogically based family reconstitutions with official census returns. The reconstitution confirms that the resurgence of Aboriginal Victoria during the late twentieth

29 Bruce Elder, Blood on the Wattle: Massacres and Maltreatments of Aboriginal Australians since 1788 (Sydney, 2003); Ian Clark, Scars in the Landscape: A Register of Massacre Sites in Western Victoria, 1803-1859 (Canberra I995); Critchett, Distant Field. 
Fig. 4 Changes in Aboriginal Populations by County as Shown in Censuses from i 86 I to I9OI

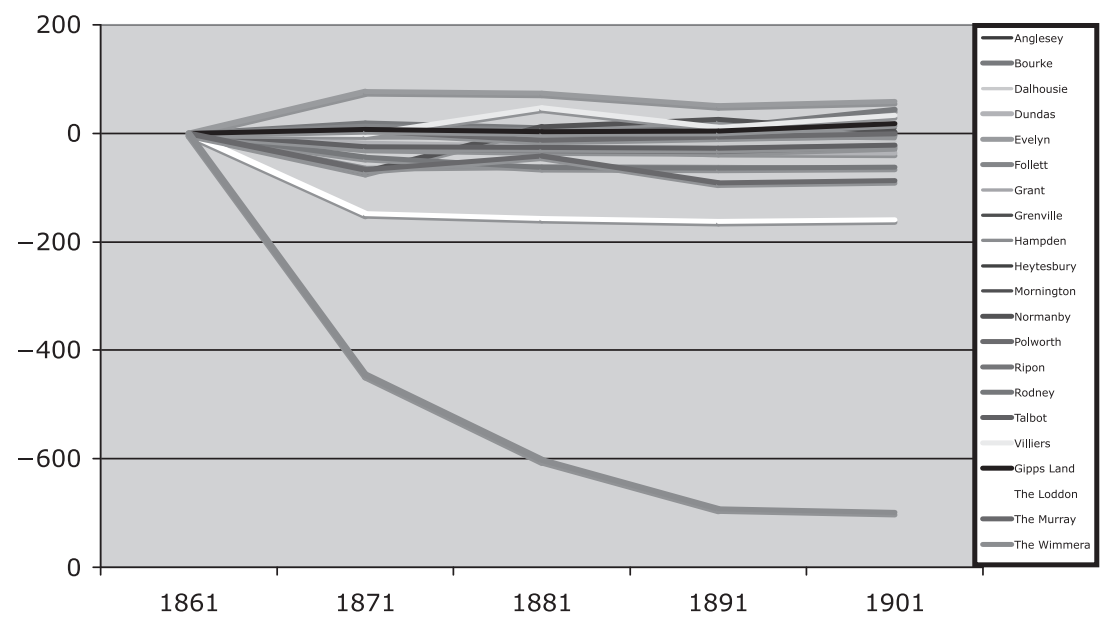

century was the result of the rejection of fractional identity and invisibility by the Aboriginal people themselves. They had never disappeared; they had been rendered invisible only by legislative fiat. The other, more startling, finding - that the surviving population is descended almost entirely from those under the protection of the colonial state-invites a revision of the historiography of reserves and Aboriginal protection, at least in Victoria. After the completion of white settlement, the protection legislation and the structures that it generated undoubtedly became instruments of oppression and control. One interpretation of the findings herein might be that during the frontier period, the Protection Board played a benevolent, protective role more in keeping with their name. Nonetheless, the fact that the Board extended protection to the remnants of the populations only after their lands had been taken and settlement had been consolidated may well indicate that it was simply another agent of dispossession. 
